\title{
Tìm hiểu biến động giá xăng trong bối cảnh dịch COVID-19
}

\author{
Trần Thị Ngọc Mai, Nguyễn Đức Mạnh, Nguyễn Trọng Minh \\ Lê Hồng Thảo My, Đặng Vĩnh Nam \\ Đại học Quốc gia Hà Nội, Hà Nội \\ Xuân Thủy, Cầu Giấy, Hà Nội
}

Preprint DOI: https://osf.io/p28jg

Trong bài luận ngắn này, chúng tôi sẽ trình bày phần thảo luận về sự biến động của giá xăng dầu, dự báo các khả năng có thể xảy ra, hạn chế của nghiên cứu.

\section{Thảo luận}

Covid-19 đang ảnh hưởng rất lớn đến đời sống của con người, khiến cho cuộc sống con người bị đảo lộn và làm ảnh hưởng đến rất nhiều nền kinh tế thế giới. Không nằm ngoài ngoại lệ, xăng cũng là mặt hàng chịu nhiều biến động bất ổn trên thị trường toàn cầu do ảnh hưởng của đại dịch COVID-19 (La, 2020).

Trong bối cảnh bình thường mới hậu đại dịch, chính phủ các nước trên thế giới cũng như Việt Nam đã đưa ra nhiều kế hoạch mở cửa, kích cầu kinh tế nhằm phục hồi sức mạnh kinh tế sau những tháng giãn cách "ảm đạm”. Người dân sau những ngày giãn cách được trở lại lại cuộc sống bình thường thì vô cùng vui mừng, đón chờ những thay đổi mới để nhanh chóng phục hồi kinh tế sau dịch. Tuy nhiên, giá xăng sau vài tháng ổn định lại đột ngột tăng đã làm cho nhiều người dân rơi vào tình cảnh "dở khóc dở cười" vì vừa trở lại hoạt động chưa lâu đã phải "méo mặt" vì giá xăng dầu tăng quá mạnh, nhiều doanh nghiệp thì rơi vào cảnh"tiến thoái lưỡng nan". Theo các chuyên gia kinh tế đánh giá thì hiện tượng biến động mạnh của giá xăng dầu này là một yếu tố bất ngờ, ảnh hưởng do bối cảnh xã hội thay đổi:

Thư nhất, sự bất đồng giữa các nước tiêu thụ lượng xăng dầu lớn như Mỹ, Ân Độ với liên minh các nước cung cấp dầu mỏ chính của thế giới- OPEC+. Sau những ngày tháng dãn cách dài, nhiều nước đồng loạt mở cửa nền kinh tế, điều này là cú hích lớn, đẩy lượng cầu xăng dầu tăng mạnh. Các nước đồng loạt gia tăng nhu cầu dự trữ xăng dầu, tuy nhiên OPEC+ lại quyết định giữa nguyên sản lượng cung cấp hàng năm, không nhất trí việc tăng sản lượng (do ảnh hưởng của nhiều yếu tố). Cung không đáp ứng đủ cầu đã làm cho giá xăng tăng lên nhanh chóng. Đây là một tác nhân quan trọng gây ra hiện tượng tăng giá xăng dầu mạnh trong những tháng cuối năm 2021- thời gian mở cửa.(PARASKOVA, 2021)

Thư hai, yếu tố về điều kiện tự nhiên, và nguồn cung nguyên liệu hóa thạch khác cũng là một nhân tố đáng lưu tâm. Theo các chuyên gia, mùa đông năm nay sẽ lạnh và khắc nghiệt hơn so với các năm trước, cho nên nhu cầu về sưởi ấm tăng cao. Điều này kéo theo nhu cầu tiêu thụ vật 
liệu cung cấp nhiệt như than tăng cao. Trong khi đó, than lại đang thiếu hụt trầm trọng nguồn cung do đại dịch kéo dài ảnh hưởng tới sản lượng khai thác, cũng như vấn đề giảm lượng than do khai thác nhiều.(Thanh, 2021)(Trinh, 2022)

Thú $b a$, nhiều nước có lượng xăng dầu dự trữ giảm mạnh do thời gian dịch bệnh kéo dài, hoạt động kinh tế đóng băng, đặc biệt là hoạt động xuất nhập khẩu gần như "tê liệt" trong nhiều tháng.(An, 2021)

Nhiều tác nhân bất ngờ và tác nhân có từ trước đã tạo nên một thời kỳ "khủng hoảng” xăng dầu thời kỳ hậu đại dịch. Nhưng theo các chuyên gia kinh tế thì đây là điều bất thường chỉ xảy ra trong ngắn hạn, không kéo dài lâu. Do những vấn đề đị chính trị này có thể giải quyết nếu các nước thống nhất tiếng nói, tăng nguồn cung khi lượng cầu tăng vọt.(VTC, 2021) Việt Nam chủ yếu dựa vào nguồn xăng dầu nhập khẩu cho nên giá xăng dầu cũng tăng theo giá chung của thị trường thế giới.

Mặc dù được dự báo là giá xăng sẽ giảm trong thời gian tương đối ngắn, nhưng việc giá xăng tăng đã ảnh hưởng không nhỏ đến đời sống sinh hoạt của người dân. Theo báo cáo, nhiều mặt hàng liên quan cũng đồng loạt tăng mạnh: như giá gas đã tăng đột biến (có khi lên đến nửa triệu một bình)(Hiển, 2021), giá các loại vật liệu xây dựng cũng tăng như giá thép, xi măng được ghi nhận là đã tăng mạnh trong thời gian qua (Phương, 2021), nhiều doanh nghiệp GTVT rơi vào cảnh tăng giá cũng dở mà giảm giá cũng căng (Đại, 2021), giá của nhiều mặt hàng tiêu dùng cũng tăng do phí vận chuyển tăng nhẹ do mặt hàng thiết yếu của ngành GTVT là xăng dầu.... Theo ghi nhận của vụ trưởng bộ công thương thì CPI tháng 11 tăng hơn so các tháng trước chủ yếu do giá xăng tăng mạnh (HA.NV, 2021)... Việc nhiều mặt hàng quan trọng tăng giá sẽ làm thay đổi tương đối khá nhiều thói quen sinh hoạt của nhiều người (Nguyễn Đứa Thành, Bùi Trinh, 2009). Trên thực tế, vì giá gas tăng mà nhiều gia đình đã lựa chọn sử dụng bếp điện thay thế để tiết kiệm chi phí, nhiều gia đình cũng hoãn dự định xây dựng do giá vật liệu tăng mạnh...

Nhưng thời gian gần đây, giá xăng dầu đã có hiện tượng giảm nhẹ do sự thay đổi chính sách của nhiều quốc gia đã khiến nguồn cung đứt gãy được nối lại. Trong đó, theo ghi nhận, OPEC+ đã chấp nhận tăng sản lượng khai thác để đáp ứng nhu cầu về xăng dầu. Điều này sẽ giảm bớt áp lực về giá cả nhiều mặt hàng tăng trong dịp cận Tết.

\section{Dự báo về các khả năng có thể xảy ra trong tương lai}

Giá xăng dầu có thể sẽ ổn định trong thời gian tới khi nhiều nước trên thế giới đang e sợ một chủng virus mới, điều này sẽ tạo trở ngại cho quá trình mở cửa của nhiều quốc gia. Điều này sẽ tạo nên sự sụt giảm trong nhu cầu về xăng dầu trong thời gian sắp tới.(BBT, 2021)

Về dài hạn, giá xăng dầu có thể sẽ tiếp tục biến động do sự thay đổi liên tục trong các chính sách của các quốc gia về điều kiện mở cửa cũng như nguồn cung của xăng dầu, theo dự báo của WHO thì virus corona có thể sẽ biến đổi không ngừng để tạo ra biến chủng mới(Scientists, 2021). Sự biến động của xăng dầu có thể sẽ làm thay đổi nhiều hơn nữa thói quen tiêu dùng của người dân. Vì vậy, cần có những nghiên cứu chuyên sâu hơn để đánh giá xác thực hơn những khả năng có thể xảy ra trong những năm tới.

Nếu giá xăng dầu tiếp tục tăng trong thời gian tới thì đến năm 2022 có thể sẽ xảy ra một thời kỳ lạm phát lớn(Sơn, 2021). Do xăng dầu là mặt hàng thiết yếu của mọi gia đình cũng như là mặt 
hàng không thể thay thế nhanh chóng của các ngành công nghiệp trọng điểm của các quốc gia trên thế giới nói chung và Việt Nam nói riêng.

\section{Hạn chế của nghiên cứu}

Về mặt tích cực, nghiên cứu này đã đưa ra một cái nhìn tổng quan về vấn đề giá xăng dầu tăng mạnh trong các tháng cuối năm 2021 - thời kỳ dịch COVID-19 diễn ra còn tương đối phức tạp. Nghiên cứu này còn đưa ra được nhiều kết luận phong phú dưới nhiều khía cạnh; đưa ra nhiều kịch bản trong tương lai, bảng biểu xác đáng, có số liệu cụ thể; đề xuất nhiều phương hướng để ổn định giá xăng trong nước. Về mặt hạn chế, do yếu tố hạn chế thời gian và nhân lực nên nghiên cứu chưa thu thập được nhiều số liệu từ đánh giá thực tế, đồng thời cũng chưa đánh giá được phản ánh của người dân trước sự thay đổi về giá xăng trong các tháng cuối năm. Nghiên cứu chỉ đưa ra được những vấn đề khá hẹp chưa mở rộng được các nước khác để đánh giá toàn diện. Và nghiên cứu được chưa đưa ra nhiều kết luận từ các nghiên cứu khác (chủ yếu lấy tư liệu từ các báo trong nước). Ý nghĩa của nghiên cứu này: Nghiên cứu này được thực hiện ngay trong thời kỳ giá xăng dầu tăng vào năm 2021 nên đã đưa ra được nhiều thông tin hữu ích cho các nghiên cứu sau. Nghiên cứu này có thể cung cấp những thông tin nền tảng để phục vụ cho các nghiên cứu chuyên sâu về sau.

Tóm lại, cùng với quá trình chuyển đổi nền kinh tế từ tập trung, bao cấp sang nền kinh tế tự quản lý của Nhà nước, hoạt động phân phối xăng dầu cũng trải qua các giai đoạn nhiều biến động. Từ phương thức cung cấp theo định lượng, nhất quán về mức giá đến việc quy định mua bán theo nhu cầu trong mùa dịch Covid 19. Để tiếp cận với thị trường xăng dầu nhiều biến động đó, Nhà nước đã nhiều lần tùy chỉnh cơ chế quản lý vĩ mô về kinh doanh xăng dầu với những chính sách phù hợp cho từng giai đoạn. Không những trong nước, thị trường xăng dầu quốc tế cũng đang nâng cao và đẩy mạnh việc mua bán, xuất nhập khẩu mạnh mẽ về xăng dầu, cho thấy đây là đặc thù của mặt hàng không co giãn. Trên cơ sở phân tích, đánh giá và nhìn nhận mọi góc cạnh về thị trường, chúng ta vẫn luôn khẳng định những bước tiến mới, sự phát triển về thị trường kinh doanh xăng dầu. Cần đối mặt với nhận hạn chế, thách thức và đặt ra các vấn đề để tiếp tục cải thiện, đổi mới thị trường xăng dầu trong nước và quốc tế. Về dài hạn, để giải quyết căn cơ vấn đề an ninh năng lượng (Xăng) thì cần sử dụng hệ xử lý thông tin 3D (Vuong, Q.H., 2022; Vuong \& Napier, 2014), tập trung vào thông tin truyền thông (loại bỏ kiểm duyệt các thông tin sai lệch), lắng nghe ý kiến chuyên gia trong lĩnh vực năng lượng..., tạo các kênh trao đổi giữa các bên liên quan. Bằng cách này tìm ra được hệ giải pháp sáng tạo giúp đạt được hài hòa các mục tiêu kinh tế, xã hội bền vững.

\section{Tài liệu tham khảo:}

An, B. (2021). Dự trũ dầu thô Mỹ sụt giảm kỷ lục. Petrol Times.

BBT. (2021). Giá xăng dầu lại sắp giảm mạnh? VTV News. https://vtv.vn/kinh-te/gia-Xang-daulai-sap-giam-manh-20211204155044277.htm

Đại, Đ. (2021). Xăng dầu tăng "sốc”, doanh nghiệp vận tải lao đao. Diễn Đàn Doanh Nghiệp. https://diendandoanhnghiep.vn/xang-dau-tang-soc-doanh-nghiep-van-tai-lao-dao210625.html

HA.NV. (2021). Chỉ số giá tiêu dùng 11 tháng 2021 tăng 1,84\%. Báo Điện Tử Đảng Cộng Sản 
Việt Nam. https://dangcongsan.vn/kinh-te/chi-so-gia-tieu-dung-11-thang-2021-tang-1-84598340.html

Hiển, N. (2021). Tù ngày mai 1-11, giá gas bán lẻ sẽ trên 500.000 đồng mỗi bình 12kg. Tuổi Trẻ Online. https://tuoitre.vn/tu-ngay-mai-1-11-gia-gas-ban-le-se-tren-500-000-dong-moi-binh$12 \mathrm{~kg}-20211031172218073 . \mathrm{htm}$

La, V. P. et al. (2020). Policy response, social media and science journalism for the sustainability of the public health system amid the COVID-19 outbreak: The vietnam lessons. Sustainability (Switzerland), 12(7). https://doi.org/10.3390/su12072931

Nguyễn Đứa Thành, Bùi Trinh, Đ. N. T. (2009). Ảnh hưởng của tăng giá xăng dầu: Một số phân tích định lượng ban đầu. Tạp Chí Khoa Học ĐHQGHN, 25-38.

PARASKOVA, T. (2021). OPEC+ Meeting Ends: Cartel Won't Produce Extra Crude. Oilprice.Com. https://oilprice.com/Energy/Crude-Oil/OPEC-Meeting-Ends-Cartel-WontProduce-Extra-Crude.html

Phương, M. (2021). Hệ luỵ khó luờng tù “bão giá” vật liệu xây dưng. Báo Điện Tử Đảng Cộng Sản Việt Nam.

Scientists. (2021). Tracking SARS-CoV-2 variants. https://www.who.int/en/activities/trackingSARS-CoV-2-variants/

Sơn, M. (2021). Thống đốc: Rủi ro lạm phát năm 2022 rất lớn. Vietnam Express. https://vnexpress.net/thong-doc-rui-ro-lam-phat-nam-2022-rat-lon-4384720.html

Thanh, H. (2021). La Nina đe dọa khủng hoảng năng luợng trầm trọng hơn trong mùa đông. Báo Tin Tức Thông Tấn Xã Việt Nam.

Trinh, D. (2022). Châu Âu có thể cạn kiệt khí đốt trong mùa Đông này. Báo Tin Tức Thông Tấn Xã Việt Nam.

VTC. (2021). Chuyên gia lý giải nghịch lý giá xăng tăng thì "phi mã̃”, giảm thì "nhỏ giọt." Bùi Ngọc Sơn. https://www.youtube.com/watch?v=npgPSnckMiM\&t=4s

Vuong, Q.H., et al. (2022). Covid-19 vaccines production and societal immunization under the serendipity-mindsponge-3D knowledge management theory and conceptual framework. Humanities \& Social Sciences Communications, 9, 22. Retrieved from: https://www.nature.com/articles/s41599-022-01034-6

Vuong, Q. H., \& Napier, N. K. (2014). Making creativity: the value of multiple filters in the innovation process. International Journal of Transitions and Innovation Systems, 3(4), 294 327. https://doi.org/10.1504/ijtis.2014.068306 